Article

\title{
Boosting fuel cell catalysis by surface doping of W on Pd nanocubes
}

\author{
Fawad Ahmad a , Laihao Luo a, Xu Li a, Hongwen Huang b,*, Jie Zeng a,\# \\ a Hefei National Laboratory for Physical Sciences at the Microscale, Key Laboratory of Strongly-Coupled Quantum Matter Physics of Chinese Academy of \\ Sciences, Department of Chemical Physics, University of Science and Technology of China, Hefei 230026, Anhui, China \\ b College of Materials Science and Engineering, Hunan province key laboratory for advanced carbon materials and applied technology, Hunan University, \\ Changsha 410082, Hunan, China
}

\section{A R T I C L E I N F}

\section{Article history:}

Received 11 May 2018

Accepted 18 May 2018

Published 5 July 2018

\section{Keywords:}

Pd-based electrocatalyst

Surface-doping process

Oxygen reduction reaction

Ethanol oxidation reaction

d-band center

\begin{abstract}
A B S T R A C T
The development of active and durable non-Pt electrocatalysts with well-defined microstructure is of great importance to both fuel cell applications and fundamental understanding. Herein, we report a surface-doping process to prepare well-defined W-doped Pd nanocubes with a tunable atomic percent of $\mathrm{W}$ from 0 to $1.5 \%$ by using the Pd nanocubes as seeds. The obtained $1.2 \% \mathrm{~W}$-doped Pd nanocubes/C exhibited greatly enhanced electrocatalytic performance toward oxygen reduction reaction in alkaline media, presenting an enhancement factor of 4.7 in specific activity and 2.5 in mass activity compared to the activity of a commercial Pt/C catalyst. The downshift of the d-band center due to a negative charge transfer from $\mathrm{W}$ to $\mathrm{Pd}$ intrinsically accounts for such improvement in activity by weakening the adsorption of reaction intermediates. Also, the $1.2 \% \mathrm{~W}$-doped Pd nanocubes/C showed superior catalytic properties for the ethanol oxidation reaction, showing great potential for serving as a bifunctional electrocatalyst in fuel cells.
\end{abstract}

(C) 2018, Dalian Institute of Chemical Physics, Chinese Academy of Sciences. Published by Elsevier B.V. All rights reserved.

\section{Introduction}

As the oxygen reduction reaction (ORR) is a rate-determining process in a number of electrochemical energy conversion devices ranging from fuel cells to metal-air batteries, highly active and durable electrocatalysts to accelerate the sluggish kinetics of ORR are the key to improving the performance of these devices [1-3]. Up to now, Pt-based nanocatalysts represent the most effective electrocatalysts toward ORR, and this can be ascribed to their unique electronic structure and excellent chemical stability [4-7]. However, the pro- hibitive cost and increasing scarcity of Pt has greatly hindered the widespread commercialization of the associated devices. As a result, finding non-Pt electrocatalysts with superior activity toward ORR and durability is technologically important [8-12].

Palladium (Pd), which not only possesses a similar electronic structure and chemical stability to Pt, but also is more abundant than Pt, has thus been regarded as a promising alternative electrocatalyst [13-20]. However, Pd intrinsically binds oxygenated species too strongly, as demonstrated by prior experimental and theoretical studies, leading to difficulty in releasing the adsorbed intermediates and thus insufficient

\footnotetext{
*Corresponding author. Tel: +86-551-63603545; E-mail: huanghw@hnu.edu.cn

\# Corresponding author. Tel: +86-551-63603545; E-mail: zengj@ustc.edu.cn

This work was supported by Collaborative Innovation Center of Suzhou Nano Science and Technology, MOST of China (2014CB932700), the National Natural Science Foundation of China $(21603208,21573206)$, Key Research Program of Frontier Sciences of the CAS (QYZDBSSW-SLH017), Anhui Provincial Key Scientific and Technological Project (1704a0902013), Major Program of Development Foundation of Hefei Center for Physical Science and Technology (2017FXZY002), Fundamental Research Funds for the Central Universities and CAS-TWAS president's fellowship. DOI: 10.1016/S1872-2067(18)63102-X | http://www.sciencedirect.com/science/journal/18722067 | Chin. J. Catal., Vol. 39, No. 7, July 2018
} 
catalytic activity toward ORR [21,22]. So far, a few strategies have been exploited to boost the catalytic activity of Pd-based electrocatalysts toward ORR by weakening the binding of adsorbed oxygenated species, e.g., alloying transition metals (Fe, $\mathrm{Co}, \mathrm{Ni}$, etc.) with $\mathrm{Pd}$, introducing surface strain, or tuning the microstructure [23-28]. Despite great progress in improving the catalytic properties, the complex structural features of most reported Pd-based electrocatalysts prevent a clear understanding of this enhancement in catalytic activity. It is thus highly desirable to develop improved Pd-based electrocatalysts with well-defined microstructure. Herein, we report a surface-doping process to prepare well-defined W-doped $\mathrm{Pd}$ nanocubes with a tunable atomic percent of $\mathrm{W}$ from 0 to $1.5 \%$ by using Pd nanocubes as seeds. The obtained $1.2 \% \mathrm{~W}$-doped $\mathrm{Pd}$ nanocubes/C displayed substantially improved electrocatalytic performance toward the ORR and the ethanol oxide reaction (EOR) in alkaline media. Based upon the well-defined microstructure, the origin of this enhancement in catalytic activity was further elucidated by analyzing the surface electronic structure.

\section{Experimental}

\subsection{Chemicals}

Sodium tetrachloropalladate (II) $\left(\mathrm{Na}_{2} \mathrm{PdCl}_{4}, 98 \%\right)$, poly(vinyl pyrrolidone) (PVP, $M \mathrm{w} \approx 55000$ ), potassium bromide ( $\mathrm{KBr}, \geq 99.0 \%$ ), L-ascorbic acid (AA, $\geq 99.0 \%$ ), palladium (II) acetylacetonate $\left(\mathrm{Pd}(\mathrm{acac})_{2}, 99 \%\right)$, and tungsten hexacarbonyl (W(CO) 6 , 97\%) were all obtained from Sigma-Aldrich. Ethanol $\left(\mathrm{C}_{2} \mathrm{H}_{5} \mathrm{OH}\right)$ and benzyl alcohol $\left(\mathrm{C}_{7} \mathrm{H}_{8} \mathrm{O}\right)$ were all purchased from Sinopharm Chemical Reagent Co. Ltd (Shanghai, China). All of the chemicals were used without further purification. Ultrapure Millipore water $\left(18.2 \mathrm{M} \Omega \mathrm{cm}^{-1}\right)$ was used in all our experiments.

\subsection{Synthesis of Pd nanocubes}

In a typical synthesis, $8.0 \mathrm{~mL}$ of an aqueous solution containing $105 \mathrm{mg}$ of PVP, $60 \mathrm{mg}$ of $\mathrm{AA}$, and $300 \mathrm{mg}$ of $\mathrm{KBr}$ were placed in a $20-\mathrm{mL}$ vial and pre-heated to $80^{\circ} \mathrm{C}$ in an oil bath with magnetic stirring for $10 \mathrm{~min}$. Subsequently, $3.0 \mathrm{~mL}$ of an aqueous solution containing $57 \mathrm{mg}$ of $\mathrm{Na}_{2} \mathrm{PdCl}_{4}$ were quickly injected with a pipette. After the vial had been capped, the reaction was continued for $3 \mathrm{~h}$. Pd nanocubes of roughly $11 \mathrm{~nm}$ in size were obtained. The product was collected by centrifugation, washed three times with water, and re-dispersed in $11 \mathrm{~mL}$ of benzyl alcohol (1.8 $\mathrm{mg} \mathrm{mL}^{-1}$ ) for further use.

\subsection{Synthesis of $W$-doped $P d$ nanocubes}

In a typical synthesis of $1.2 \% \mathrm{~W}$-doped Pd nanocubes, 10.0 $\mathrm{mL}$ of benzyl alcohol solution containing $3.6 \mathrm{mg}$ of Pd cubic seeds, $5 \mathrm{mg}$ of $\mathrm{Pd}(\mathrm{acac})_{2}$, and $4.0 \mathrm{mg}$ of $\mathrm{W}(\mathrm{CO})_{6}$ were placed in a 25-mL three-necked bottle and heated at $180{ }^{\circ} \mathrm{C}$ under a $\mathrm{N}_{2}$ atmosphere. The 0.8 and $1.5 \% \mathrm{~W}$-doped $\mathrm{Pd}$ nanocubes were synthesized using the same procedure except for the addition of 2.0 and $8.0 \mathrm{mg}$ of $\mathrm{W}(\mathrm{CO})_{6}$, respectively. After the reaction had proceeded for $1 \mathrm{~h}$, the obtained products were collected by washing the sample with ethanol three times. The sample was finally dispersed into ethanol prior to characterization and electrochemical tests.

\subsection{Characterization}

Transmission electron microscopy (TEM) images were taken using a Hitachi HT7650 microscope operated at $120 \mathrm{kV}$. High-angle annular dark-field scanning transmission electron microscopy (HAADF-STEM) images and energy-dispersive $\mathrm{X}$-ray spectroscopy (EDX) analyses were collected on a JEOL ARM-200F field-emission transmission electron microscope operating at an accelerating voltage of $200 \mathrm{kV}$ using $\mathrm{Cu}$-based TEM grids. X-ray diffraction (XRD) characterization was performed using a Philips X'Pert Pro X-ray diffractometer with a monochromatized $\mathrm{Cu} K_{\alpha}$ radiation source and a wavelength of $0.1542 \mathrm{~nm}$. Compositional analyses were carried out by inductively coupled plasma-atomic emission spectrometry (ICP-AES, Atomscan Advantage, Thermo Jarrell Ash, USA). Surface valence band spectra were collected by high-resolution X-ray photoemission spectroscopy (XPS) on the nanoparticle monolayers. These were recorded on an ESCALAB-250 spectrometer having a monochromatic $\mathrm{Al} K_{\alpha} \mathrm{X}$-ray source $(h v=1486.6 \mathrm{eV})$, with a spot size of $500 \mu \mathrm{m}$.

\subsection{Electrochemical measurements}

\subsubsection{Preparation of working electrodes}

Prior to the measurements, the catalyst was prepared by loading the sample on Vulcan XC-72 carbon support with a Pd content of $20 \mathrm{wt} \%$. The catalyst ink was prepared by dispersing as-prepared catalyst in a mixture containing $0.745 \mathrm{~mL}$ of deionized water, $0.250 \mathrm{~mL}$ of isopropyl alcohol, and $0.005 \mathrm{~mL}$ of Nafion (5\%). Then $10 \mu \mathrm{L}$ of the suspension were deposited on the RDE. For the commercial Pt/C and Pd/C catalysts (20 wt\% metal loading), the dispersion solution (5 $\mathrm{mg} \mathrm{mL}^{-1}$ ) was prepared and sonicated for $1 \mathrm{~h}$. Four $\mu \mathrm{L}$ of the dispersion were then transferred onto the glassy carbon RDE with a geometric area of $0.196 \mathrm{~cm}^{2}$. The total loading amount of Pd or Pt for all measured catalysts was $4 \mu \mathrm{g}$ for ORR and $2 \mu \mathrm{g}$ for EOR.

\subsubsection{Electrocatalytic measurements}

Electrochemical measurements were carried out with a three electrode system on an IM6 electrochemical workstation (Zahner, Germany). A Pt wire and $\mathrm{Ag} / \mathrm{AgCl}$ electrode were used as the counter and reference electrodes, respectively. All potentials were converted to values with reference to reversible hydrogen electrode (RHE). Cyclic voltammograms (CVs) were processed in $\mathrm{KOH}\left(0.1 \mathrm{~mol} \mathrm{~L}^{-1}\right)$ solutions under a flow of $\mathrm{N}_{2}$ at a sweep rate of $50 \mathrm{mV} \mathrm{s}^{-1}$. The ORR measurements were performed in $\mathrm{O}_{2}$-saturated $0.1 \mathrm{M} \mathrm{KOH}$ at a rotation rate of $1600 \mathrm{r}$ $\mathrm{min}^{-1}$ and a sweep rate of $10 \mathrm{mV} \mathrm{s}^{-1}$. A durability test was performed at room temperature by applying cyclic sweeps between 0.4 and $1.0 \mathrm{~V}_{\mathrm{RHE}}$ in $\mathrm{O}_{2}$-saturated $0.1 \mathrm{~mol} \mathrm{~L}^{-1} \mathrm{KOH}$ at a sweep rate of $100 \mathrm{mV} \mathrm{s}^{-1}$. The mass and specific activities were 
obtained by normalizing the kinetic current to the loading Pd or Pt mass and real active surface area. The EOR measurements were conducted in an electrolyte solution containing $1.0 \mathrm{~mol}$ $\mathrm{L}^{-1} \mathrm{KOH}$ and $1.0 \mathrm{~mol} \mathrm{~L}^{-1}$ ethanol at a scan rate of $50 \mathrm{mV} \mathrm{s}^{-1}$. Chronoamperometric measurements were conducted at 0.75 $V_{\text {RHE }}$ in $1.0 \mathrm{~mol} \mathrm{~L}^{-1} \mathrm{KOH}$ and $1.0 \mathrm{~mol} \mathrm{~L}^{-1}$ ethanol solution and held for $1000 \mathrm{~s}$.

\section{Results and discussion}

\subsection{Morphology and microstructure}

Typically, the W-doped Pd nanocubes were synthesized via a two-step seed-mediated growth approach. In the first step, Pd nanocubic seeds with an average diameter of $11.0 \mathrm{~nm}$ (Fig. S1) were prepared using a protocol developed by Jin et al. [29]. The surface doping of $\mathrm{W}$ was then implemented by the addition of $\mathrm{W}(\mathrm{CO})_{6}$, together with $\mathrm{Pd}(\mathrm{acac})_{2}$, into a suspension of the preformed Pd nanocubic seeds in benzyl alcohol at $180{ }^{\circ} \mathrm{C}$ for $1 \mathrm{~h}$ (Fig. 1(a), see Supporting Information for details). The XRD pattern of the sample (Fig. S2) obtained using the standard procedure corresponds well to face-centered cubic (fcc) Pd. A representative TEM image of the sample (Fig. 1(b)) clearly shows the well-preserved cubic shape of the product after the doping process. The average size of these nanocubes was determined to be $13.0 \mathrm{~nm}$ by counting more than 100 particles (Fig. S3), implying the formation of a 1-nm-thick overgrowth layer along each side of the cube. The HAADF-STEM image recorded from an individual nanocube (Fig. 1(c)) exhibits well-defined fringes corresponding to the $\{200\}$ plane of fcc Pd. The compositional distribution was detected by EDX. As shown in Fig. 1(d), the EDS line-scanning profile definitely indicates that the $\mathrm{W}$ element is located mainly at the external surface of the cubes, suggesting the successful formation of W-doped Pd nanocubes. We further estimate that the depth of the doping layer is ca. 5 atomic layers according to the thickness of the overgrowth layer and the distribution profile of the $\mathrm{W}$. The atomic percent of $\mathrm{W}$ in the nanocubes was determined to be $1.2 \%$, by ICP-AES (hereafter we denote the sample as $1.2 \% \mathrm{~W}$-doped Pd nanocubes for convenience). XPS analysis (Fig. 1(e)) also confirms the presence of $\mathrm{Pd}$ and $\mathrm{W}$ in the obtained nanocubes. As shown in Fig. 1(e), the peaks at 341.1 and

(a)

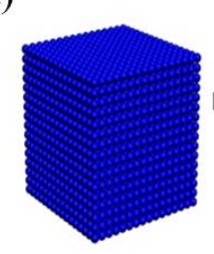

Pd nanocubes
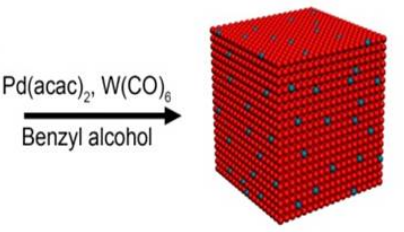

W-doped Pd nanocubes

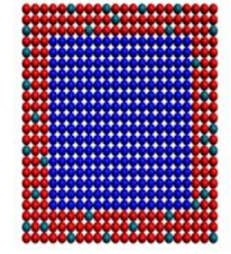

Cross-section viewed along

[100] direction
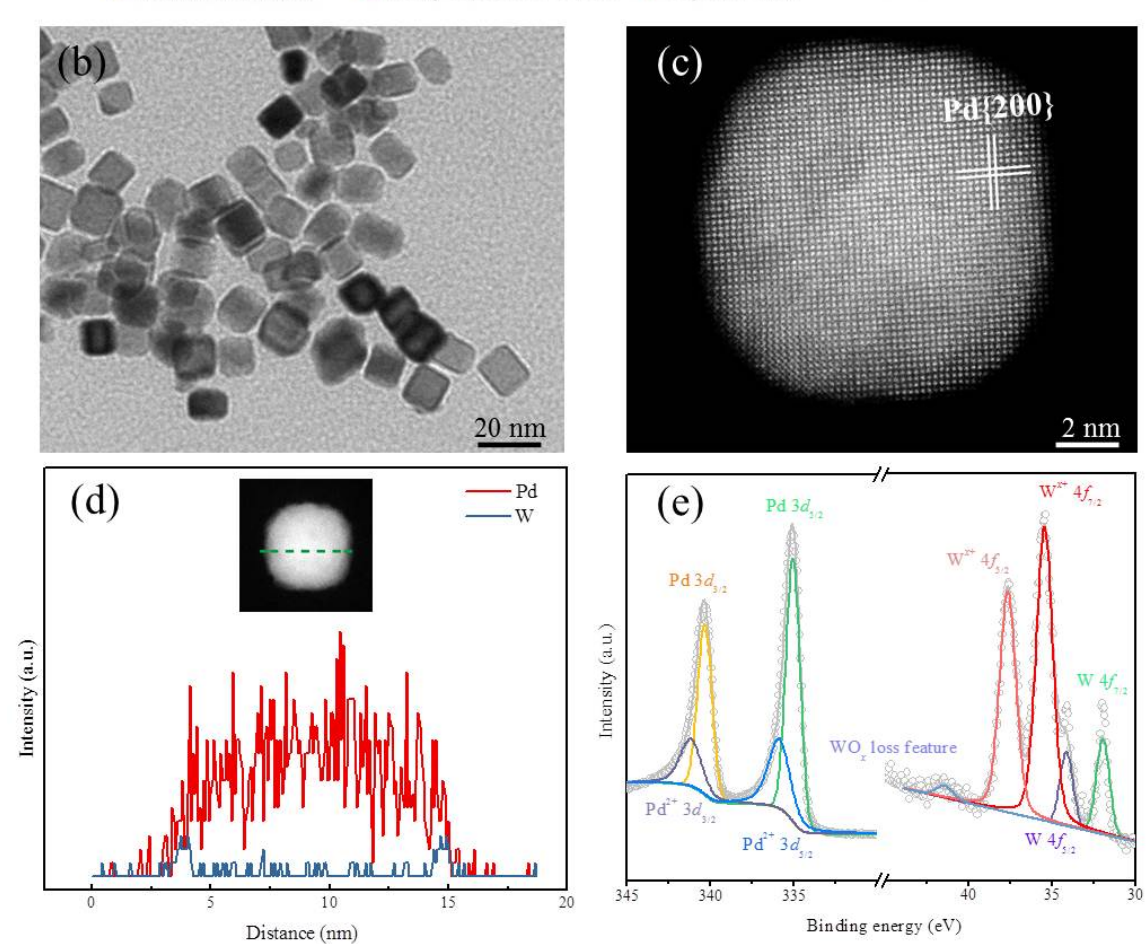

Fig. 1. (a) Schematic illustration of the formation process of W-doped Pd nanocubes. (b) TEM image of W-doped Pd nanocubes. (c) HAADF-STEM image of an individual W-doped Pd nanocube. (d) EDX line-scanning profile of an individual W-doped Pd nanocube. (e) Pd and W XPS spectra recorded from the W-doped Pd nanocubes. 
$335.9 \mathrm{eV}$ can be assigned to metallic $\mathrm{Pd} 3 d_{3 / 2}$ and $\mathrm{Pd} 3 d_{5 / 2}$ peaks, respectively [30]. $\mathrm{W}$ is present in both the oxidized state and the metallic state, with peaks at 37.8 and $35.7 \mathrm{eV}$ ascribed to $\mathrm{W}^{x+} 4 f_{5 / 2}$ and $\mathrm{W}^{x+} 4 f_{7 / 2}$, and 34.4 and $32.2 \mathrm{eV}$ ascribed to metallic $\mathrm{W} 4 f_{5 / 2}$ and $\mathrm{W} 4 f_{7 / 2}$, respectively [31]. The peak at $41.5 \mathrm{eV}$ is assigned to the $\mathrm{WO}_{x}$ loss feature, which is in good agreement with previous studies [32].

For comparison, W-doped Pd nanocubes with different doping concentrations were synthesized by simply varying the amount of $\mathrm{W}(\mathrm{CO})_{6}$ precursor. When 2.0 and $8.0 \mathrm{mg}$ of $\mathrm{W}(\mathrm{CO})_{6}$ were added, the $\mathrm{W}$ concentrations were 0.8 and 1.5 at $\%$, respectively. TEM images (Fig. S4(a) and (b)) further demonstrate the formation of $\mathrm{W}$-doped Pd nanocubes. Importantly, size distribution histograms (Fig. S4(c) and (d)), obtained by counting more than 100 particles for each sample, clearly show similar average sizes for W-doped Pd nanocubes with different concentrations of $\mathrm{W}$. The doping of $\mathrm{W}$ was also confirmed by $\mathrm{W}$ 4 XPS spectra (Fig. S4(e) and (f)). The $\mathrm{WO}_{x}$ loss feature was not found for the $0.8 \% \mathrm{~W}$-doped Pd nanocubes, which may be related to the low W content. Notably, the Pd XPS $3 d_{3 / 2}$ peak position shifted to a lower binding energy with an increase in $\mathrm{W}$ content, which can be attributed to a negative charge transfer from W to Pd. Such W-doped Pd nanocubes with similar sizes thus make them an ideal platform to investigate the effects of doping.

\subsection{Electrocatalytic activity}

The electrocatalytic ORR properties of W-doped Pd nanocubes were then evaluated using the rotating disk electrode (RDE) method. Prior to the measurement, the catalyst was prepared by loading the sample on a Vulcan XC-72 carbon support. For comparison, the ORR properties of $\mathrm{Pd}$ nanocubes/C, commercial $\mathrm{Pt} / \mathrm{C}$, and $\mathrm{Pd} / \mathrm{C}$ (20 wt\% $\mathrm{Pd}$ or $\mathrm{Pt}$ nanoparticles with an average size of $\sim 3 \mathrm{~nm}$ on Vulcan XC-72 carbon) were also measured. Fig. S5 shows CVs of different catalysts conducted at room temperature in a $\mathrm{N}_{2}$-saturated 0.1 mol L-1 KOH solution with a sweep rate of $50 \mathrm{mV} \mathrm{s}^{-1}$ in the potential range $0.16-1.26 \mathrm{~V}$ versus RHE ( $\mathrm{V}_{\mathrm{RHE}}$ ). As hydrogen can penetrate into the Pd lattice, the electrochemical surface active area (ECSA) of Pd-based catalysts was calculated based on the charge of the reduction of $\mathrm{PdO}$ at around $0.72 \mathrm{~V}_{\mathrm{RHE}}$ with correction for the double-layer, assuming $0.405 \mathrm{mC} \mathrm{cm}^{-1}$ for the reduction of a monolayer of PdO on the catalyst surface [33]. For commercial Pt/C, the ECSA was estimated based on the charge associated with the desorption of hydrogen. The specific ECSAs were determined to be 40.5, 48.5, 25.7, 23.7, 21.1 and 20.6 $\mathrm{m}^{2} \mathrm{~g}^{-1} \mathrm{Pd} / \mathrm{Pt}$ for commercial $\mathrm{Pt} / \mathrm{C}, \mathrm{Pd} / \mathrm{C}, \mathrm{Pd}$ nanocubes/C, 0.8\%W-doped $\mathrm{Pd}$ nanocubes/C, 1.2\%W-doped $\mathrm{Pd}$ nanocubes/C, and $1.5 \% \mathrm{~W}$-doped $\mathrm{Pd}$ nanocubes/C, respectively. Of note, the potential of the $\mathrm{Pd}(\mathrm{OH})_{2}$ reduction peak follows the
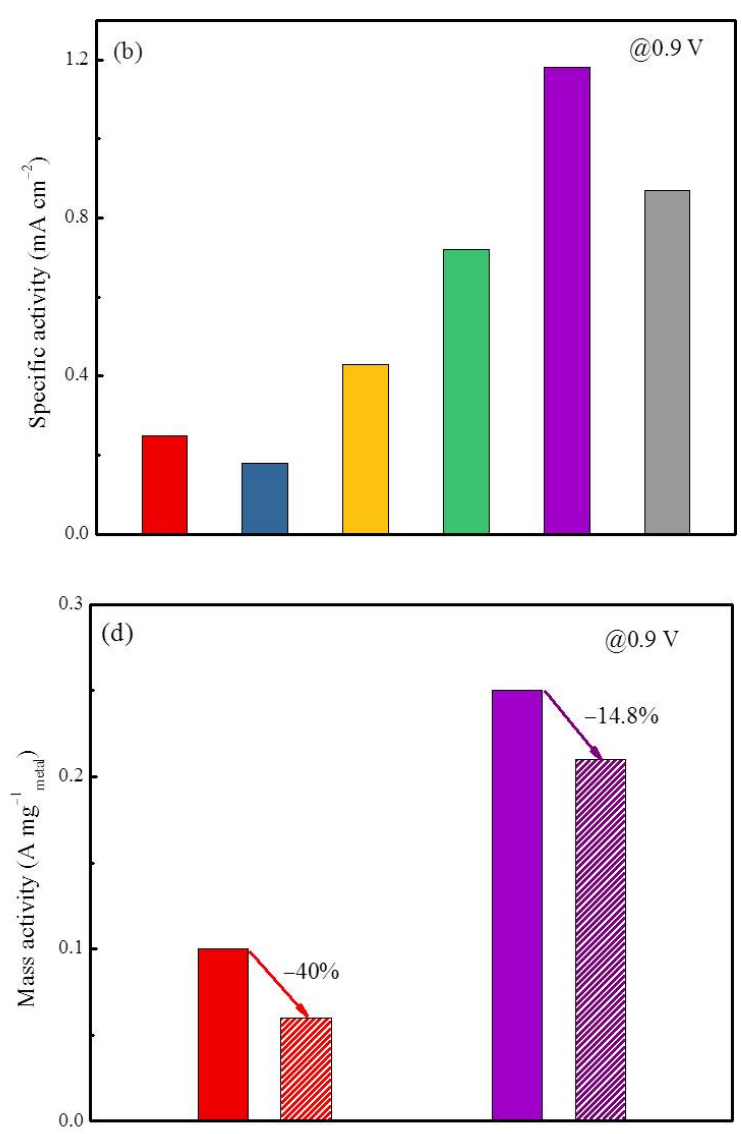

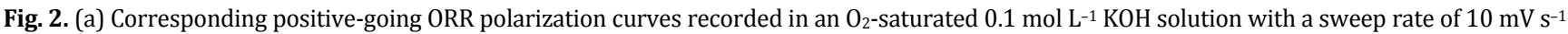
and a rotation rate of $1600 \mathrm{r} \mathrm{min}^{-1}$. (b, c) Specific and mass ORR activities given as kinetic current densities normalized to the ECSAs and metal masses of the catalysts, respectively. (d) Comparison of durability between commercial Pt/C and 1.2\%W-doped Pd nanocubes. The comparison is based on the mass activity at 0.9 RHE. The color scheme in (a) applies to all other graphs. 
trend $\mathrm{Pd} / \mathrm{C}<\mathrm{Pd}$ nanocubes $/ \mathrm{C}<1.5 \% \mathrm{~W}$-doped $\mathrm{Pd}$ cubes $/ \mathrm{C}$, indicating weak adsorption on $\mathrm{W}$-doped Pd nanocubes [15]. To compare the catalytic activities of these catalysts toward ORR, positive going ORR polarization curves were recorded at room temperature in an $\mathrm{O}_{2}$-saturated $0.1 \mathrm{~mol} \mathrm{~L}^{-1} \mathrm{KOH}$ solution, as shown in Fig. 2(a). The specific and mass activities of these catalysts were then derived by normalizing the kinetic current densities, which were obtained according to the Koutecky-Levich equation, against the ECSA and Pd or Pt mass, respectively. As shown in Fig. 2(b) and (c), the 1.2\%W-doped Pd nanocubes exhibit the highest specific and mass activities among these catalysts. At $0.9 \mathrm{~V}_{\mathrm{RHE}}$, the specific activity of $1.2 \% \mathrm{~W}$-doped Pd nanocubes/C was $1.18 \mathrm{~mA} \mathrm{~cm}^{-2}$, which was 4.7, 6.6, 2.7, 1.6 and 1.4 times higher than that of commercial $\mathrm{Pt} / \mathrm{C}(0.25 \mathrm{~mA} \mathrm{~cm}-2)$, commercial $\mathrm{Pd} / \mathrm{C}\left(0.18 \mathrm{~mA} \mathrm{~cm}{ }^{-2}\right), \mathrm{Pd}$ nanocubes/C $\left(0.43 \mathrm{~mA} \mathrm{~cm}^{-2}\right), 0.8 \% \mathrm{~W}$-doped $\mathrm{Pd}$ nanocubes/C $\left(0.72 \mathrm{~mA} \mathrm{~cm}^{-2}\right)$, and $1.5 \% \mathrm{~W}$-doped Pd nanocubes/C $0.87 \mathrm{~mA}$ $\mathrm{cm}^{-2}$ ), respectively. It should be noted that the specific activity of the $1.2 \% \mathrm{~W}$-doped Pd nanocubes/C catalyst surpassed most reported Pd-based catalysts for alkaline ORR [34-40]. The mass activity of these catalysts also showed the same trend as the specific activity. At $0.9 \mathrm{~V}_{\mathrm{RHE}}$, the $1.2 \% \mathrm{~W}$-doped $\mathrm{Pd}$ nanocubes/C exhibited a mass activity of $0.25 \mathrm{~A} \mathrm{mg}^{-1} \mathrm{Pd}, 2.5$ times greater than that of commercial Pt/C $\left(0.10 \mathrm{~A} \mathrm{mg}^{-1} \mathrm{Pt}\right)$.

We further investigated the long-term durability of the 1.2\%W-doped Pd nanocubes/C through an accelerated durability test (ADT) at room temperature, and benchmarked it with commercial Pt/C catalyst. As shown in Fig. 2(d), the 1.2\%W-doped Pd nanocubes still maintained a mass activity of $0.21 \mathrm{~A} \mathrm{mg}^{-1} \mathrm{Pd}$ after 10,000 cycles in $\mathrm{O}_{2}$-saturated conditions, showing a decrease of $14.8 \%$ with respect to the initial activity. By contrast, Pt/C lost $40.0 \%$ of its initial mass activity. Generally, the durability of catalytic properties is highly dependent on structural stability. We then checked the morphologies of these catalysts before and after 10,000 electrochemical cycles by TEM (Fig. S6). Unlike the serious aggregation found for the commercial Pt/C catalyst, the morphology of the $1.2 \% \mathrm{~W}$-doped Pd nanocubes showed negligible change, suggesting superior durability for $1.2 \% \mathrm{~W}$-doped Pd nanocubes/C catalyst.

In order to develop a deeper understanding of the improved specific activity of the W-doped Pd nanocubes toward ORR, we experimentally analyzed the variation of electronic structures for the W-doped Pd nanocubes by surface valence-band photoemission spectra using high-resolution XPS. As shown in Fig. 3 , the positions of d-band centers (with regard to Fermi level) for W-doped Pd nanocubes monotonously shifts downwards from -2.49 to $-3.08 \mathrm{eV}$ as the $\mathrm{W}$ content increases from 0 to $1.5 \%$, consistent with the positive shift trend for the reduction potential of $\mathrm{Pd}(\mathrm{OH})_{2}$. The downshifting of $d$-band centers with increasing $\mathrm{W}$ content can be ascribed to the accumulated negative charge density of the Pd atoms due to a negative charge transfer from $\mathrm{W}$ to $\mathrm{Pd}[41,42]$. In principle, the downshift of d-band centers can pull more of the antibonding states below the Fermi level, which in turn weakens the adsorption of reaction intermediates [43-45]. As such, it can be concluded that the downshifting of $d$-band centers arising from the doping of $\mathrm{W}$ is an intrinsic cause for the improved specific activity of 1.2\%W-doped Pd nanocubes toward ORR given that the Pd binds oxygenated species too strongly $[46,47]$. It is noted that the catalytic activity of W-doped Pd nanocubes shows a volcano-like variation when further increasing the content of $\mathrm{W}$ to $1.5 \%$, which can be rationalized based on the Sabatier principle [48].

Finally, we evaluated the electrocatalytic performance of the $1.2 \% \mathrm{~W}$-doped Pd nanocubes/C toward the EOR in alkaline medium, a half reaction at the anode of direct ethanol fuel cells (DEFCs). As shown in Fig. 4(a), the catalytic activities of the catalysts were characterized by $\mathrm{CV}$ in a mixture of $1.0 \mathrm{~mol} \mathrm{~L}^{-1}$ $\mathrm{KOH}$ and $1.0 \mathrm{M}$ ethanol aqueous solution. The $1.2 \% \mathrm{~W}$-doped $\mathrm{Pd}$ nanocubes/C showed the highest forward peak current density of $6.6 \mathrm{~A} \mathrm{mg}^{-1} \mathrm{Pd}$, which was 2.2 and 5.1 times higher than those for Pd nanocubes/C (3.0 A mg-1 $\left.{ }^{\mathrm{Pd}}\right)$ and commercial Pd/C (1.3 A $\mathrm{mg}^{-1} \mathrm{Pd}$ ), respectively. Such greatly enhanced catalytic activity of 1.2\%W-doped Pd nanocubes/C can be attributed to surface doping with $\mathrm{W}$, which downshifts the d-band center of the catalyst and thus facilitates the efficient release of free Pd active

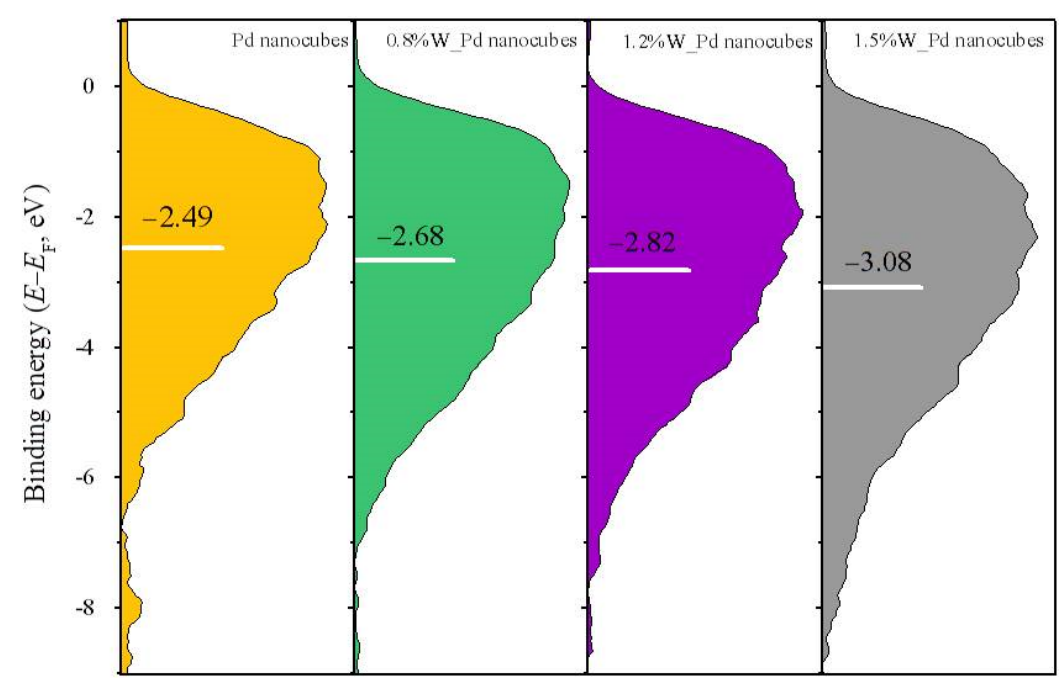

Fig. 3. Surface valence band photoemission spectra of pure Pd nanocubes and Pd nanocubes with different amounts of W doping. The $d$-band centers are marked with white lines. 

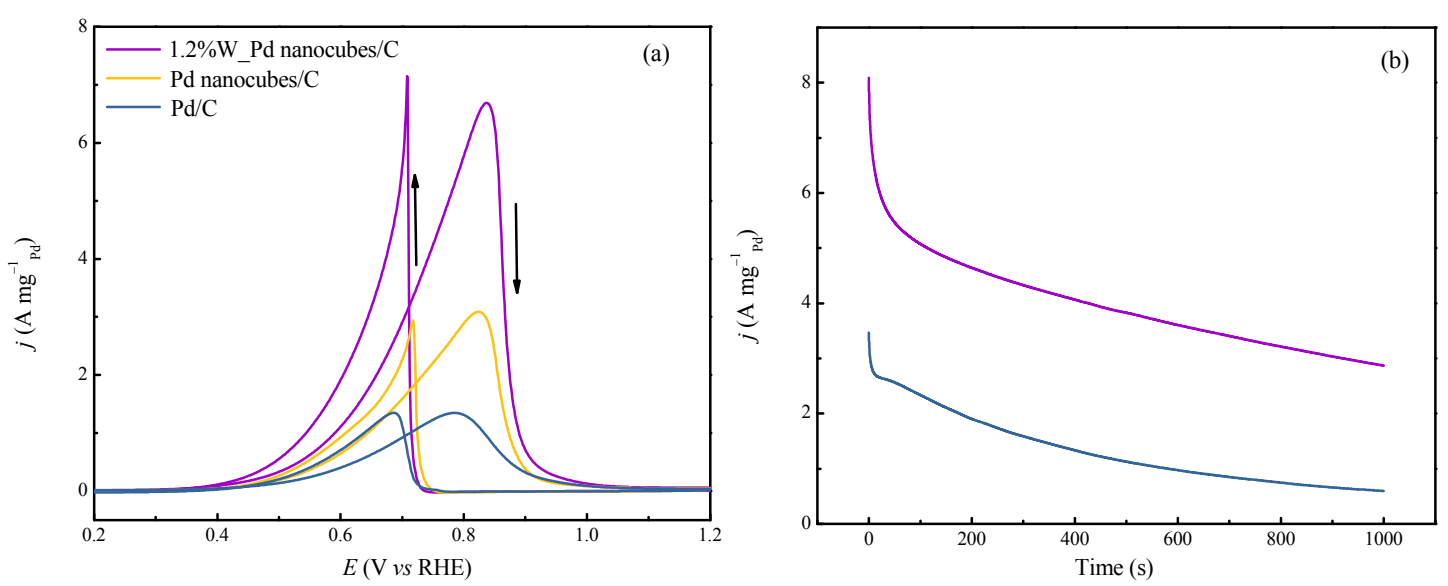

Fig. 4. (a) CVs of $1.2 \% \mathrm{~W}$-doped Pd nanocubes/C, Pd nanocubes/C and commercial Pd/C in $1.0 \mathrm{~mol} \mathrm{~L}^{-1} \mathrm{KOH}+1.0 \mathrm{~mol} \mathrm{~L} \mathrm{~L}^{-1}$ ethanol solution. (b) Chronoamperometric measurements of $1.2 \% \mathrm{~W}$-doped Pd nanocubes/C and commercial Pd/C. The color scheme in (a) applies to both graphs.

sites by weakening the adsorption of carbonyl species. Chronoamperometry (CA) was employed to evaluate the stability of these catalysts. As shown in Fig. 4(b), initial rapid decreases in current density were observed for both $1.2 \% \mathrm{~W}$-doped Pd nanocubes/C and Pd/C catalysts, which could be ascribed to the accumulation of strongly adsorbed reaction intermediates on the surface active sites. Importantly, the $1.2 \% \mathrm{~W}$-doped Pd nanocubes/C showed much greater durability with respect to commercial Pd/C catalyst after a 1000-s durability test. Taken together, we have demonstrated $1.2 \% \mathrm{~W}$-doped Pd nanocubes as an excellent catalyst for catalyzing both ORR and EOR in DEFCs with both superb catalytic activity and durability.

\section{Conclusions}

In conclusion, we have demonstrated a surface-doping process to prepare well-defined W-doped Pd nanocubes with a tunable atomic percent of $\mathrm{W}$ from 0 to $1.5 \%$ by using the $\mathrm{Pd}$ nanocubes as seeds. Compared with commercial Pt/C catalyst, the 1.2\%W-doped Pd nanocubes/C shows 4.7 and 2.5-fold enhancement in specific activity and mass activity, respectively. Moreover, even after 10,000 cycles of accelerated durability test in $\mathrm{O}_{2}$-saturated conditions, the $1.2 \% \mathrm{~W}$-doped $\mathrm{Pd}$ nanocubes/C catalyst presents a drop of $14.8 \%$ in mass activity, compared to a large drop of $40.0 \%$ for commercial Pt/C. In catalyzing EOR, the $1.2 \% \mathrm{~W}$-doped $\mathrm{Pd}$ nanocubes/C catalyst exhibits a peak current density of $6.6 \mathrm{~A} \mathrm{mg}^{-1} \mathrm{Pd}$, which is 5.1 and 2.2 times higher than for commercial $\mathrm{Pd} / \mathrm{C}$ and $\mathrm{Pd}$ nanocubes/C, respectively. The $1.2 \% \mathrm{~W}$-doped $\mathrm{Pd}$ nanocube catalyst also displays a superior catalytic stability toward EOR compared to commercial $\mathrm{Pd} / \mathrm{C}$. The improved catalytic activity of the W-doped Pd nanocubes/C catalyst can be ascribed to the optimized d-band center based on analysis of the electronic structure, which effectively regulates the adsorption of reaction intermediates on the surface of the catalyst. We believe that our work not only provides a promising bifunctional electrocatalyst for fuel cells but also offers a general strategy for the design of optimized well- defined heterogeneous catalysts by a surface-doping process.

\section{References}

[1] X. Zhao, S. Chen, Z. C. Fang, J. Ding, W. Sang, Y. C. Wang, J. Zhao, Z. M. Peng, J. Zeng, J. Am. Chem. Soc., 2015, 137, 2804-2807.

[2] Z. W. Seh, J. Kibsgaard, C. F. Dickens, J. K. Nørskov, T. F. Jaramillo, I. Chorkendorff, Science, 2017, 355, eaad4998.

[3] L. S. Cao, S. F. Jiang, G. Zhang, X. J. Tang, X. P. Qin, Z. G. Shao, B. L. Yi, Chin. J. Catal., 2017, 38, 1196-1206.

[4] H. W. Huang, K. Li, Z. Chen, L. H. Luo, Y. Q. Gu, D. Y. Zhang, C. Ma, R. Si, J. L. Yang, Z. M. Peng, J. Zeng, J. Am. Chem. Soc., 2017, 139, 8152-8159.

[5] V. R. Stamenkovic, B. Fowler, B. S. Mun, G. Wang, P. N. Ross, C. A. Lucas, N. M. Markovic, Science, 2007, 315, 493-497.

[6] C. Chen, Y. J. Kang, Z. Y. Huo, Z. W. Zhu, W. Y. Huang, H. L. Xin, J. D. Snyder, D. G. Li, J. A. Herron, M. Mavrikakis, M. F. Chi, K. L. More, Y. D. Li, N. M. Markovic, G. A. Somorjai, P. D. Yang, V. R. Stamenkovic, Science, 2014, 343, 1339-1343.

[7] J. F. Kong, W. L. Cheng, Chin. J. Catal., 2017, 28, 951-969.

[8] S. J. Guo, X. Zhang, W. L. Zhu, K. He, D. Su, A. Mendoza-Garcia, S. F. Ho, G. Lu, S. H. Sun, J. Am. Chem. Soc., 2014, 136, 15026-15033.

[9] D. L. Wang, S. F. Liu, J. Wang, R. Q. Lin, M. Kawasaki, E. Rus, K. E. Silberstein, M. A. Lowe, F. Lin, D. Nordlund, H. F. Liu, D. A. Muller, H. L. Xin, H. D. Abruña, Nat. Commun., 2016, 7, 11941.

[10] B. Y. Xia, Y. Yan, N. Li, H. B. Wu, X. W. Lou, X. Wang, Nat. Energy, 2016, 1, 15006.

[11] J. K. Nørskov, J. Rossmeisl, A. Logadottir, L. Lindqvist, J. R. Kitchin, T. Bligaard, H. Jónsson, J. Phys. Chem. B, 2004, 108, 17886-17892.

[12] C. Du, X. H. Gao, W. Chen, Chin. J. Catal., 2016, 37, 1049-1061.

[13] M. H. Shao, J. Power Sources, 2011, 196, 2433-2444.

[14] M. H. Shao, T. Huang, P. Liu, J. Zhang, K. Sasaki, M. B. Vukmirovic, R. R. Adzic, Langmuir, 2006, 22, 10409-10415.

[15] D. F. Gao, H. Zhou, J. Wang, S. Miao, F. Yang, G. X. Wang, J. G. Wang, X. H. Bao, J. Am. Chem. Soc., 2015, 137, 4288-4291.

[16] D. F. Gao, H. Zhou, F. Cai, D. N. Wang, Y. F. Hu, B. Jiang, W. B. Cai, X. Q. Chen, R. Si, F. Yang, S. Miao, J. G. Wang, G. X. Wang, X. Bao, Nano Res., 2017, 10, 2181-2191.

[17] F. Cai, D. F. Gao, H. Zhou, G. X. Wang, T. He, H. M. Gong, S. Miao, F. Yang, J. G. Wang, X. H. Bao, Chem. Sci., 2017, 8, 2569-2573.

[18] L. L. Yan, A. Brouzgou, Y. Z. Meng, M. Xiao, P. Tsiakaras, S. Q. Song, Appl. Catal. B, 2014, 150, 268-274.

[19] A. Brouzgou, L. Yan, S. Song, P. Tsiakaras, Appl. Catal. B, 2014, 150, 268-274. 


\section{Graphical Abstract}

Chin. J. Catal., 2018, 39: 1202-1209 doi: 10.1016/S1872-2067(18)63102-X

\section{Boosting fuel cell catalysis by surface doping of $\mathrm{W}$ on Pd nanocubes}

Fawad Ahmad, Laihao Luo, Xu Li, Hongwen Huang *, Jie Zeng * University of Science and Technology of China; Hunan University

W-doped Pd nanocubes were synthesized by a surface-doping process using Pd nanocubes as seeds. The W-doped Pd nanocubes showed substantially improved fuel cell catalysis, including the alkaline oxygen reduction reaction and the ethanol oxidation reaction, which can be attributed to a downshift of the d-band center of the catalyst due to negative charge transfer from $\mathrm{W}$ to $\mathrm{Pd}$.

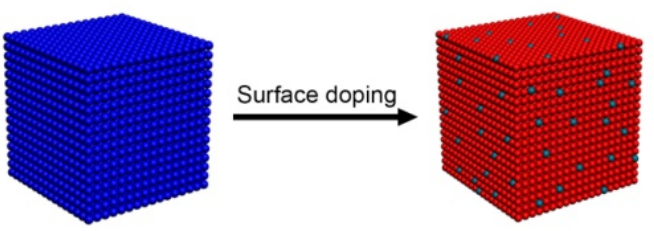

Pd nanocubes

W-doped Pd nanocubes

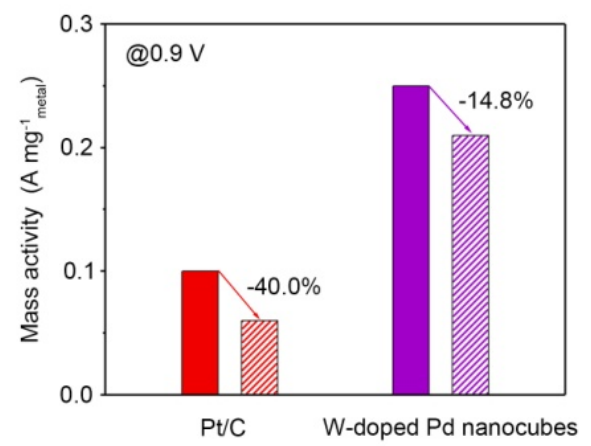

[20] G. Andreadis, S. Q. Song, P. Tsiakaras, J. Power Sources, 2006, 157, 657-665.

[21] M. H. Shao, P. Liu, J. L. Zhang, R. Adzic, J. Phys. Chem. B, 2007, 111, 6772-6775.

[22] M. H. Shao, K. Sasaki, R. R. Adzic, J. Am. Chem. Soc., 2006, 128, 3526-3527.

[23] G. M. Jiang, H. Y. Zhu, X. Zhang, B. Shen, L. H. Wu, S. Zhang, G. Lu, Z. B. Wu, S. H. Sun, ACS Nano, 2015, 9, 11014-11022.

[24] J. L. Fernandez, V. Raghuveer, A. Manthiram, A. J. Bard, J. Am. Chem. Soc., 2005, 127, 13100-13101.

[25] L. Y. Chen, H. Guo, T. Fujita, A. Hirata, W. Zhang, A. Inoue, M. W. Chen, Adv. Func. Mat., 2011, 21, 4364-4370.

[26] L. Z. Bu, Q. Shao, Y. C. Pi, J. L. Yao, M. C. Luo, J. P. Lang, S. Hwang, H. L. Xin, B. L. Huang, J. Guo, D. Su, S. J. Guo, X. Q. Huang, Chem, 2018, 4, 359-371.

[27] L. Zhang, S. Chen, Y. M. Dai, Z. Q. Shen, M. J. Wei, R. J. Huang, H. L. Li, T. T. Zheng, Y. J. Zhang, S. M. Zhou, J. Zeng, ChemCatChem, 2018, 10, 925-930.

[28] M. S. Jin, H. Y. Liu, H. Zhang, Z. X. Xie, J. Y. Liu, Y. N. Xia, Nano Res., 2011, 4, 83-91.

[29] Y. Z. Lu, Y. Y. Jiang, X. H. Gao, X. D. Wang, W. Chen, J. Am. Chem. Soc., 2014, 136, 11687-11697.

[30] G. Z. Hu, F. Nitze, E. Gracia-Espino, J. Y. Ma, H. R. Barzegar, T. Sharifi, X. E. Jia, A. Shchukarev, L. Lu, C. S. Ma, G. Yang, T. Wågberg, Nat. Commun., 2014, 5, 5253.

[31] T. T. Zheng, W. Sang, Z. H. He, Q. S. Wei, B. W. Chen, H. L. Li, C. Cao, R. J. Huang, X. P. Yang, B. C. Pan, S. M. Zhou, J. Zeng, Nano Lett,, 2017, 17, 7968-7973.

[32] L. Chen, L. L. Lu, H. L. Zhu, Y. G. Chen, Y. Huang, Y. D. Li, L. Y. Wang, Nat. Commun., 2017, 8, 14136.

[33] J. Li, H. Zhou, H. Zhuo, Z. Z. Wei, G. L. Zhuang, X. Zhong, S. W. Deng, X. N. Li, J. G. Wang, J. Mater. Chem. A, 2018, 6, 2264.

[34] L. Zhang, S. Chen, Y. M. Dai, Z. Q. Shen, M. J. Wei, R. J. Huang, H. L. Li,
T. T. Zheng, Y. J. Zhang, S. M. Zhou, J. Zeng, ChemCatChem, 2018, 10, 925-930.

[35] Y. F. Chen, X. Jiang, Y. Y. Li, P. Li, Q. C. Liu, G. T. Fu, L. Xu, D. M. Sun, Y. W. Tang, Adv. Mater. Interfaces, 2017, 5, 1701015.

[36] L. X. Zuo, L. P. Jiang, J. J. Zhu, Ultrason. Sonochem., 2017, 35, 681-688.

[37] J. Li, J. X. Chen, Q. Wang, W. B. Cai, S. L. Chen, Chem. Mater., 2017, 29, 10060-10067.

[38] G. W. Wang, J. X. Guan, L. Xiao, B. Huang, N. Wu, J. T. Lu, L. Zhuang, Nano Energy, 2016, 29, 268-274.

[39] K. L. Huang, Z. T. Liu, C. L. Lee, Electrochim. Acta, 2015, 157, 78-87.

[40] Y. Z. Lu, Y. Y. Jiang, X. H. Gao, X. D. Wang, W. Chen, J. Am. Chem. Soc., 2014, 136, 11687-11697.

[41] L. B. Wang, S. T. Zhao, C. X. Liu, C. Li, X. Li, H. L. Li, Y. C. Wang, C. Ma, Z. Y. Li, J. Zeng, Nano Lett., 2015, 15, 2875-2880.

[42] J. Yang, Y. Xie, R. H. Wang, B. J. Jiang, C. G. Tian, G. Wu, J. Yin, B. Wang, H. G. Fu, ACS Appl. Mater. Interfaces, 2013, 5, 6571-6579.

[43] W. B. Zhang, L. B. Wang, H. Y. Liu, Y. P. Hao, H. L. Li, M. U. Khan, J. Zeng, Nano Lett., 2017, 17, 788-793.

[44] W. J. Tang, L. Zhang, G. Henkelman, J. Phys. Chem. Lett., 2011, 2, 1328-1331.

[45] H. W. Huang, H. H. Jia, Z. Liu, P. F. Gao, J. T. Zhao, Z. L. Luo, J. L. Yang, J. Zeng, Angew. Chem. Int. Ed., 2017, 56, 3594-3598.

[46] J. Greeley, I. E. L. Stephens, A. S. Bondarenko, T. P. Johansson, H. A. Hansen, T. F. Jaramillo, J. Rossmeisl, I. Chorkendorff, J. K. Nørskov, Nat. Chem., 2009, 1, 552-556.

[47] A. J. Medford, A. Vojvodic, J. S. Hummelshøj, J. Voss, F. Abild-Pedersen, F. Studt, T. Bligaard, A. Nilsson, J. K. Nørskov, J. Catal., 2015, 328, 36-42.

[48] W. X. Du, K. E. Mackenzie, D. F. Milano, N. A. Deskins, D. Su, X. W. Teng, ACS Catal., 2012, 2, 287-297. 


\title{
通过表面铇掺杂大幅提升钯纳米立方体的燃料电池催化性能

\author{
Fawad Ahmad ${ }^{\mathrm{a}}$, 罗赖吴 ${ }^{\mathrm{a}}$, 李 旭 ${ }^{\mathrm{a}}$, 黄宏文 ${ }^{\mathrm{b},{ }^{*}}$, 曾 杰, ${ }^{\mathrm{a}, \#}$ \\ a中国科学技术大学, 合肥微尺度物质科学国家研究中心, \\ 中国科学院强耦合量子材料物理重点实验室, 安徽合肥 230026

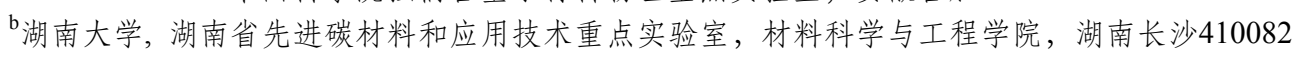

\begin{abstract}
摘要: 发展兼具高活性和高稳定性的规整非铂电化学催化剂无论对于燃料电池的推广应用还是基础研究都具有重要意义. 我们将钯纳米立方体(Pd nanocubes)作为晶种, 使用表面掺杂的手段制备了一种表面结构规整的铇掺杂钯纳米立方体 (W-doped Pd nanocubes). 通过改变合成过程中所加入羰基铇前驱体的量以调控表面铇的原子比例, 继而获得了铇原子比 例分别为 $0 \%, 0.8 \%, 1.2 \%, 1.5 \%$ 的纳米立方体. 所制W-doped Pd nanocubes/C催化剂在碱性条件下的氧还原反应中表现出 优异性能, 其中 $1.2 \% \mathrm{~W}$-doped Pd nanocubes/C催化剂性能最佳, 在 $0.9 \mathrm{~V}_{\mathrm{RHE}}$ 时比活性达 $1.18 \mathrm{~mA} \mathrm{~cm}$, 质量活性达 $0.25 \mathrm{~A}$ $\mathrm{mg}^{-1}{ }_{\mathrm{Pd}}$, 分别是商业 $\mathrm{Pt} / \mathrm{C}$ 催化剂的 4.7 倍和 2.5 倍. 研究表明, 随着铇的掺杂量从 $0 \%$ 增至 $1.5 \%$, 铇掺杂钯纳米立方体的 $d$ 带中心 从- $2.49 \mathrm{eV}$ 逐渐降至 $-3.08 \mathrm{eV}$. 同时, 光电子能谱结果表明, 随着铇掺杂量的增加, 钯的 $3 d$ 峰位向低能逐渐偏移, 说明了铇掺 杂导致了电荷由铇转向钯. 而 $d$ 带中心的下移能够将更多的反键态拉下费米能级, 继而导致反应中间体的吸附减弱. 因此, 由铇到钯的电荷转移导致的d带中心的下移, 继而引起的反应中间体对催化剂的吸附作用变弱是氧还原催化活性增强的原 因. 而过高的 $\mathrm{W}$ 掺杂 $(1.5 \%)$ 导致活性的降低也可以用 Sabatier规则解释. 在循环测试 10000 圈之后, $1.2 \% \mathrm{~W}$-doped $\mathrm{Pd}$ nanocubes/C催化剂的质量活性仅仅减少了 $14.8 \%$, 而商业 $\mathrm{Pt} / \mathrm{C}$ 催化剂减少了 $40 \%$, 可见其具有极佳的稳定性. 而且循环测试 之后的透射电镜表征显示, 相比于团聚严重的商业Pt/C催化剂, $1.2 \% \mathrm{~W}$-doped Pd nanocubes/C催化剂仍然分散良好, 其形貌 也几乎没有发生变化. 此外, 该催化剂对乙醇氧化反应也表现出优异的性能. 在 $1.0 \mathrm{~mol} \mathrm{~L}^{-1}$ 氢氧化钾和 $1.0 \mathrm{~mol} \mathrm{~L}^{-1}$ 乙醇混合 溶液中, 测试峰电流达 $6.6 \mathrm{~A} \mathrm{mg}^{-1}$ d, 是 $\mathrm{Pd}$ nanocubes/C催化剂的 2.2 倍, 商业 $\mathrm{Pd} / \mathrm{C}$ 催化剂的 5.1 倍. 这同样得益于适量铇掺杂 所导致的催化剂 $\mathrm{d}$ 带中心下移引起的含碳中间体吸附的削弱. 经过 $1000 \mathrm{~s}$ 的稳定性测试, $1.2 \% \mathrm{~W}$-doped Pd nanocubes/C同样 表现出高于商业 $\mathrm{Pd} / \mathrm{C}$ 催化剂的稳定性. 优异的氧还原和乙醇氧化性能表明所制 $1.2 \% \mathrm{~W}$-doped $\mathrm{Pd}$ nanocubes $/ \mathrm{C}$ 是一种极具 潜力的双功能燃料电池催化剂.
\end{abstract}

关键词: 钯基金属催化剂; 表面掺杂; 氧还原; 乙醇氧化; d带中心

收稿日期: 2018-05-11. 接受日期: 2018-05-18. 出版日期: 2018-07-05.

*通讯联系人. 电话: (0551)63603545; 电子邮箱: huanghw@hnu.edu.cn

\#通讯联系人. 电话: (0551)63603545; 电子邮箱: zengj@ustc.edu.cn

基金来源: 苏州纳米科技协同创新中心; 国家重点基础研究发展规划(973计划, 青年科学家专题项目, 2014CB932700); 国家自然 科学基金(21603208，21573206); 中国科学院前沿科学重点研究项目 (QYZDBSSW-SLH017); 安徽省科技攻关计划 (1704a0902013); 合肥物质科学技术中心重要项目培育基金(2017FXZY002); 中央高校基本科研业务费专项资金; CAS-TWAS奖 学金.

本文的电子版全文由Elsevier出版社在ScienceDirect上出版(http://www.sciencedirect.com/science/journal/18722067). 